\title{
PERSPECTIVE
}

\section{Thyroid eye disease}

\author{
Devron H Char
}

While the findings of thyroid eye disease were probably described as early as the 12 th century, controversy remains regarding the pathogenesis, pathophysiology, and management of this disease. ${ }^{12}$ Several recent laboratory and clinical studies have increased our understanding of some of these issues. This review selectively highlights those newer investigations on pathophysiology, epidemiology, and management; established concepts on thyroid eye disease have been reviewed elsewhere..$^{2-5}$

\section{Pathophysiology of eye disease}

Several hypotheses regarding the pathophysiology of thyroid eye disease are being actively investigated. Most workers believe this to be an autoimmune ophthalmic disease related to the thyroid abnormality. Historically some investigators questioned whether there was a definite link between the eye inflammation and thyroid disease, since approximately $10 \%$ of patients were euthyroid; Salvi and colleagues have shown that extensive immunological testing has demonstrated thyroid abnormalities in almost all such cases. ${ }^{6}$

Several systemic immune perturbations have been described in thyroid eye disease patients including increased interleukin 2 receptors in approximately $50 \%$ of patients. ${ }^{7}$ As several workers have pointed out, however, there is a paucity of data on immunological abnormalities in the local milieu of the orbit.

Graves' disease develops secondary to autoantibodies secreted by mainly clonally restricted intrathyroidal B cells that bind to, and act as agonists towards, the thyroid stimulating hormone (TSH) receptor. ${ }^{8}$ The large extracellular portion of this $\mathrm{G}$ protein linked receptor is antigenic. ${ }^{9}$ Several investigators have queried whether the TSH receptor could be the pathogenic shared thyroid orbital antigen. Some groups have shown messenger RNA (mRNA) transcripts for this receptor in orbital tissue, while others have not. ${ }^{10-13}$ It is also uncertain whether normal TSH receptor protein, altered protein, or what level of expression is present in orbital tissues. While antibodies towards TSH have been demonstrated in some thyroid patients, they do not appear to be either of significantly greater titre or prevalence in patients with eye disease. ${ }^{6}{ }^{10-1214}$

A dichotomy of opinion exists about what is the primary target cell in the orbital autoimmune process; some favour the fibroblast while others argue it is the extraocular muscle. Until a molecular treatment approach can be developed to abort the inciting orbital event, it probably is not vital to know which is the primary cell type for autoimmune attack. In addition to direct inflammatory cell damage to the primary target cell, contiguous spillover effects by both cells and soluble factors alter surrounding orbital tissue. Intuitively, the muscle would appear to be a more likely primary target, since clinically the muscles are almost always involved, while orbital fat less frequently shows signs of lymphocytic infiltration or isolated volume expansion on imaging or at surgery. ${ }^{2}$ In contrast, most histologi- cal studies have shown little damage to the muscle itself during the acute phase of ophthalmic disease; most inflammation is noted in the perimysial compartment between the individual muscle cells. ${ }^{2}$

Hiromatsu and colleagues demonstrated a $64 \mathrm{kDa}$ antigen that is shared between the thyroid gland and eye muscle. ${ }^{15}$ This antigen has $63 \%$ nucleotide homology with tropomodulin which binds tropomyosin. ${ }^{16}$ Further analyses with that $64 \mathrm{kDa}$ antigen, cloned from an eye muscle cDNA library, showed there was a much wider tissue distribution than just the thyroid and orbital tissues. ${ }^{17}{ }^{18}$ Other investigators have noted a minimal correlation between patients' serological reactivity toward this $64 \mathrm{kDa}$ antigen and thyroid eye disease status. ${ }^{19-22}$ However, as Elisei and colleagues pointed out, the use of expression libraries to identify appropriate antigens is limited by the linear epitopes produced from cDNA libraries that are often not as antigenic as in their native configuration. ${ }^{23}$ Antibody reactivity towards this $64 \mathrm{kDa}$ muscle associated antigen is probably a secondary phenomenon; more frequent reactivity in patients with only thyroid disease suggests it is a marker of thyroid autoimmunity, even though there is some cross reactivity with orbital antigens. ${ }^{24-26}$ Other investigators have not found this antigen elicits a demonstrable $T$ cell response. ${ }^{27}$ It has previously been pointed out that almost all investigations have been on systemic rather than intraorbital antibodies or $\mathrm{T}$ cells, and this study design most probably would not detect a localised intraorbital immunological response. ${ }^{28}$ An intriguing negative study was performed with the middle ear musculature of five patients with thyroid eye disease, because these ear muscles are very similar in structure to the recti muscles. However, no evidence of middle ear muscle abnormalities was noted. ${ }^{29}$

There are more in vitro data consistent with the hypothesis that orbital fibroblasts are central to the inflammatory fibrotic changes that occur in thyroid related orbital disease. Bahn and her colleagues have demonstrated, in vitro, that the orbital fibroblasts are both perturbated by, and can alter, intraorbital immune responses. ${ }^{30}$ Inflammatory cells, including CD4 and CD8 T cells, produce several cytokines including interferon gamma, tumour necrosis factor $\alpha$, and interleukin $1 \alpha$ in the orbital connective tissues and these have been demonstrated in orbital decompression specimens. ${ }^{31} 32$

Several cytokines, as well as corticosteroids, modulate cell surface antigens on fibroblasts by altering expression of heat shock protein, intercellular adhesion molecules, and class II histocompatibility antigens. ${ }^{30}{ }^{33-37}$ These molecules can upregulate a local immune or inflammatory response and allow the fibroblast to serve as an antigen presentation site. The immunological perturbations in and around the orbital fibroblast could cause inflammation and fibrosis of the contiguous extraocular muscles. Fibroblast proliferation has been shown to be stimulated by several cytokines including interleukin $1 \alpha$, interleukin 4 , insulin-like growth 
factor, tumour growth factor $\beta$, and platelet derived growth factors. ${ }^{38}$ Several of the above cytokines, as well as other factors produced as a result of an inflammatory process, can also increase glycosoaminoglycan (GAG) production by the fibroblasts. GAG is a hydrophilic molecule whose production directly increases orbital volume and absorbs extracellular fluid with resultant oedematous changes in the orbital connective tissue. ${ }^{39-41}$ Hypoxia also increases GAG production; epidemiological data that demonstrate an association between the eye disease and smoking could be partially explained on that basis, although this remains speculative. ${ }^{41}$

Several cardinal issues are still unknown about the initiation of the orbital process. Firstly, what is the pathogenic event and antigen? Secondly, why are there a number of incongruities in the clinical pattern such as the more frequent involvement of the inferior recti, marked orbital asymmetry, or the rarity of this disease in non-Graves' thyroid disease including Hashimoto's thyroiditis? Thirdly, what is the role of vascular engorgement? Feldon and others have documented increased size of the superior ophthalmic vein; they proposed that a decrease in venous outflow may be important in the aetiology and maintenance of orbital. swelling in this disease. ${ }^{42}{ }^{43}$ Are these demonstrable venous changes primary or secondary? Finally, among a myriad of unanswered questions, what is the role of the TSH receptor in thyroid eye disease? Bahn and colleagues have noted aberrant TSH receptor mRNA in orbital fibroblasts of some women with a threonine for proline substitution. ${ }^{44}$ What is the significance of these and other findings?

\section{Hyperthyroidism therapy and eye disease}

The effect of the systemic hyperthyroidism therapy on the development and progression of the eye disease is uncertain. A compendium of retrospective series did not demonstrate a difference in the incidence of thyroid eye findings as an effect of surgical, medical, or radioactive iodine thyroid therapy. ${ }^{2}$ Thyroid status after systemic Graves' disease therapy does seem important, and several clinical studies have shown a higher incidence of ophthalmopathy in patients who are allowed to become clinically hypothyroid. ${ }^{44-47}$

Tallstedt and co-workers, in a randomised study of 114 patients between 35 and 55 years old, noted significantly more ophthalmopathy in those treated with radioactive iodine (33\%: 13 of 39 patients) compared with patients who had either surgery or antithyroid medicine (10$16 \%) .^{48}$ The observation of possibly deleterious effects with radioactive iodine has engendered a great deal of controversy. ${ }^{49}$

Several possible explanations were given that might have led to inadvertent, spurious results in the Tallstedt study. ${ }^{50}$ One, in the radioactive iodine group the patients had a higher incidence of smoking; the association between smoking and more severe eye disease is discussed elsewhere in this review. Two, 18 of the patients treated with radioactive iodine required more than one dose of the radioactive iodine-131 isotope; in the 21 who required only a single radioactive iodine dose, only one developed eye disease. Patients with more severe hyperthyroidism have a higher risk of developing eye disease, so that those patients who required additional radioactive iodine were at greater risk of developing ophthalmopathy. ${ }^{51}{ }^{52}$ Three, the posttreatment management of thyroid status was different in the surgery, medicine, and iodine-131 groups. In the latter subset, patients did not receive hormone replacement until they were hypothyroid in contrast with the other two groups who were treated with thyroxine. The hypothyroid state that developed in most of the patients treated with radioactive iodine may have adversely affected the eye disease. $^{53}$

What is the optimal management of hyperthyroid patients to minimise the development of severe eye disease? Previous data have demonstrated that fewer than $5 \%$ of patients will develop ophthalmic disease severe enough to require corticosteroids, radiation, or surgery. ${ }^{2}$ Eye status before radioactive iodine is a risk factor for more severe ophthalmopathy. ${ }^{54}$ In one study, 16 of 30 patients with eye disease before treatment with radioactive iodine developed proptosis measurements of $>20 \mathrm{~mm}$; in a study with a limited sample size the relative risk was 4.9 for severe ophthalmopathy to develop in patients with eye findings compared with patients without ocular signs before therapy for hyperthyroidism. ${ }^{54}$ These data are compatible with an earlier study that noted $33 \%$ of patients with significant eye findings had progression as against $7 \%$ of those with only mild eye disease. ${ }^{56}$ In patients with symptomatic eye disease before treatment of the systemic hyperthyroidism, coverage with corticosteroids seems advisable. In a study by Bartalena and colleagues nine of 16 patients treated with radioactive iodine alone had worsening of pre-existing eye disease compared with none of 21 who received radioactive iodine with systemic prednisone. ${ }^{57}$

Prolonged hypothyroidism after therapy is a risk factor for progression of eye disease as is the inability to achieve a euthyroid state. ${ }^{55}$ Tallstedt and co-workers noted that treatment with laevothyroxine immediately after radioactive iodine resulted in a lower incidence of significant eye findings. ${ }^{58}$

Many thyroid specialists, especially in the USA, believe that properly administered radioactive iodine, with complete ablation of the gland, steroid coverage if there is significant inflammation, and thyroid replacement to avoid hypothyroidism is an excellent option in patients with eye disease. There is controversy regarding this point.

Several systemic treatment issues remain unresolved. Thyroid antigens are released after radioactive iodine, and these could make the eye disease worse; isolated case reports have also documented these changes. ${ }^{59-61}$ As an alternative to radioactive iodine, a potential advantage of thiourea drug therapy is that these agents appear to downregulate intrathyroid lymphoid cells and might mute autoimmune ophthalmopathy, and may decrease class II histocompatibility antigen expression on both the gland and on orbital fibroblasts. ${ }^{59}{ }^{62}$ The major problem with these drugs has been their inability to produce complete long lasting remissions in most patients, even when thyroid replacement is added to the regimen. ${ }^{63}$

\section{Thyroid eye disease epidemiology}

Middle aged women are most likely to have both Graves' disease and eye findings, although older men often develop more severe ophthalmopathy. ${ }^{2}{ }^{6466}$ In contrast, ophthalmopathy is much less frequent in younger patients with Graves' disease. ${ }^{67} 68$

In an epidemiological study, Bartley observed that the age-adjusted incidence of thyroid eye disease for women was 16/100 000/year (compared with 2.9 for males), and this was not altered over a 15 year period. ${ }^{69}$ In that latter series, the family history was positive in over $60 \%$ of cases, and the risk for therapeutic intervention was significantly higher in patients who presented at over 50 years of old. In older patients the 5 year cumulative risk for ophthalmic surgical intervention was over $20 \%$ compared with $12 \%$ in younger patients. ${ }^{69}$ Other workers have also noted worse disease in older, male, and white patients compared with Asian subjects. ${ }^{70} \mathrm{71}$ 
Several studies have demonstrated an association between cigarette smoking and ophthalmopathy. ${ }^{72-77}$ In the retrospective study by Bartalena and coworkers of 1730 patients with various types of thyroid disease, $64 \%$ of cases with severe eye disease were smokers compared with $48 \%$ of non-ophthalmic hyperthyroid patients and $28 \%$ of controls. ${ }^{74}$ Heavy smokers had more severe eye disease. ${ }^{71}{ }^{74}$ Tellez et al noted that cessation of smoking did not seem to affect ophthalmopathy. ${ }^{71}$ The molecular basis for the association between smoking and eye disease is uncertain. As mentioned above, in vitro hypoxia results in increased GAG production by fibroblasts. Other possibilities are the increased thyroglobulin levels in smokers or the adrenergic effects of nicotine.

\section{Management of eye disease}

There has been a paucity of major advances in the clinical management of thyroid eye disease since the publication of several comprehensive reviews. ${ }^{2}{ }^{78}$ Given the limited amount of new therapeutic data, a few selective alterations in patient management are emphasised in this section.

Fortunately, fewer than $5 \%$ of patients with Graves' disease will have severe enough eye findings that require systemic corticosteroids or more aggressive therapy. In the majority of patients, temporary supportive therapy, occasionally augmented with topical $\beta$ adrenergic blocking agents, are all that is necessary, until this systemic hyperthyroidism is brought under control and the eye disease remits spontaneously.

What are newer therapeutic developments for significant thyroid orbitopathy? One, as previously discussed, hyperthyroid patients with active eye disease, probably should be covered with systemic steroids while the gland is being ablated or suppressed. ${ }^{57}$ Two, several studies have queried the relative efficacy of several agents for patients with significant orbital inflammatory findings. Two prospective studies have been reported on cyclosporine in thyroid eye disease. ${ }^{79}{ }^{80}$ Prummel and colleagues compared a 3 month course of prednisone $(60 \mathrm{mg} /$ day for 2 weeks then tapered) with cyclosporine $(7.5 \mathrm{mg} / \mathrm{kg} /$ day $)$ in 36 patients. The steroid treated patients did significantly better than those who received cyclosporine ( 11 of 18 versus 4 of 18 responders). At 1 year almost $50 \%$ required either surgery or radiation. ${ }^{79}$ Kahaly and colleagues compared relatively long term systemic prednisone alone with prednisolone plus moderately high dose $(5-7.5 \mathrm{mg} / \mathrm{kg} /$ day $)$ cyclosporine for 1 year. The combined group did better than the patients who received only steroids both in terms of a more rapid onset of remission and its maintenance. ${ }^{80}$ Similarly, in another small study it appeared a combination of oral prednisone plus conventional photon radiation $(20 \mathrm{~Gy}$ in 10 divided fractions) was more efficacious than corticosteroids alone in the control of orbital inflammation. ${ }^{81}$

Approximately 1000 patients with thyroid eye disease have been reported after orbital radiation (generally $20 \mathrm{~Gy}$ in 10 divided fractions.) This modality has been effective in about two thirds of patients who have mainly inflammatory findings; about $30 \%$ of patients still require some surgical procedure at a later date. ${ }^{82}$

Several studies have demonstrated the potential for magnetic resonance imaging (MRI) or spectroscopy to predict therapeutic response with these non-surgical treatments. A major clinical problem is the differentiation of patients in the inflammatory versus the fibrotic stage of thyroid eye disease. In the former group medical therapy is indicated but cosmetic eyelid or muscle surgery should be delayed. In the latter group medical therapy is not effective and as soon as patients have stable fibrosis, eyelids and muscles can be safely moved. We had previously demon- strated in an animal model that the delineation between inflammatory and fibrotic changes could be ascertained within 24 hours with ${ }^{31} \mathrm{P}$ magnetic resonance spectroscopy (MRS) ${ }^{83}$ Conventional MRI equipment can be used to approximate some of these factors; however, the sensitivity and accuracy of various approaches is uncertain. In one study, using a low magnetic strength unit with short inversion time recovery (STIR), they noted the signal intensity ratio between muscles and orbital connective tissue could be used to predict response to therapy. ${ }^{84}$ In several studies $\mathrm{T}_{2}$ extraocular muscle relaxation times have correlated with disease status and response to therapy. Short relaxation times are associated with fibrosis while longer times indicate oedema; those patients with prolonged times were more likely to respond to medicines. ${ }^{85-87}$ An additional interesting imaging study showed that ultrasound, compared with MRI, was not very accurate in measuring muscle size. ${ }^{88}$

Orbital decompression surgery, in the USA, is being performed more commonly, especially for cosmetic disfigurement as a result of proptosis. Several different approaches including conventional sinus or orbital surgery, advancement of the orbital rim, removal of orbital fat, and nasal endoscopic surgery have been described. ${ }^{289-92}$ Most of these surgical changes are of relatively minor importance. In my experience, if there is compression of the optic nerve with minimal to moderate proptosis, the secondary strabismus, a bête noir of that type of surgery, is uncommon. If marked proptosis is the indication for decompression, experience has taught us that adding removal of the lateral wall with relatively less sinus surgery, markedly decreases the incidence of new or increased strabismus to about $15 \%$.

Several authors have commented on the problems of rehabilitating patients with thyroid eye strabismus, especially those with new onset cyclotorsion deviations that can occur after decompression. ${ }^{93}$ Adjustable sutures are advantageous in the management of thyroid myopathy. ${ }^{94}$ Botulinum toxin has not been shown to be of widespread benefit in this disease. Eyelid surgery remains essentially unchanged.

Finally, several groups are attempting to use newer approaches such as modulating cytokines for thyroid orbitopathy, as has been initiated in some rheumatological diseases; however, there are insufficient data to comment on the possible efficacy of these and other experimental molecular biology approaches. ${ }^{95}$

DEVRON H CHAR

Department of Ophthalmology,

University of California, San Francisco, USA

1 Elgood C, ed. Medicine in Persia. New York: Hoeber, 1934:54-5.

2 Char DH. Thyroid eye disease. 3rd ed. Oxford: Butterworth-Heinemann, 1996.

3 Gorman CA, Waller RR, Dyer JA. The eye and orbit in thyroid disease. New York: Raven Press, 1984

4 Karger B. Endocrine ophthalmopathy: molecular, immunological and clinical aspects. In: Kahaly G, ed. Dev Ophthalmol 1993:vol 25.

5 Burch HB, Wartofsky L. Graves' ophthalmopathy: current concepts regarding pathogenesis and management. Endocrine Rev 1993;14:747-93.

6 Salvi M, Zhang Z-G, Haegert D, Woo M, Liberman A, Cadarso L, et al. Salvi M, Zhang Z-G, Haegert D, Woo M, Liberman A, Cadarso L, et al.
Patients with endocrine ophthalmopathy not associated with overt thyroid disease have multiple thyroid immunologic abnormalities. $f$ Clin Endocrinol Metab 1990;70:89-94.

7 Prummel MF, Wiersinga WM, Van der Gaag R, Mourits MP, Koornneef L. Soluble IL-2 receptor levels in patients with Graves' ophthalmopathy. Clin Exp Immunol 1992;88:405-9.

8 Weetman AP, Yateman ME, Ealey PA, Black CM Reimer CB, Williams RC $\mathrm{Jr}$, et al. Thyroid-stimulating antibody activity between different immunoglobulin G subclasses. $\mathcal{f}$ Clin Invest 1990;86:723-7.

9 Parmentier M, Libert F, Maenhaut C, Lefort A, Gerard C, Perret J. Molecular cloning of the TSH receptor. Science 1989;246:1620-2.

10 Heufelder AE, Bahn RS. Evidence for the presence of a functional TSH-receptor in retroocular fibroblasts from patients with Graves' TSH-receptor in retroocular fibroblasts from pa

11 Peliciello A, Porcellini A, Ciullo I, Bonavolonta G, Avvedimento EV, Fenzi G. Expression of thyrotropin receptor mRNA in healthy and Graves' disease retro-orbital tissue. Lancet 1993;342:337-8. 
12 Paschke R, Elisei R, Vassart G, Ludgate M. Lack of evidence supporting the presence of $\mathrm{mRNA}$ for the TSH receptor in extraocular muscle. $\mathcal{F}$ Endocrinol Invest 1993;16:329-32.

13 Paschke R, Vassart G, Ludgate $M$. Current evidence for and against the TSH receptor being the common antigen in Graves' disease and thyroid associated ophthalmopathy. Clin Endocrinol 1995;42:565-9.

14 McLachlan SM, Bahn R, Rapoport B. Endocrine ophthalmopathy: a re-evaluation of the association with thyroid autoantibodies. Autoimmunity 1992;14:143-8.

15 Hiromatsu Y, Fukazawa H, Guinard F, Salvi M, How J, Wall JR. A thyroid cytotoxic antibody that cross-reacts with an eye muscle cell surface antigen may be the cause of thyroidassociated ophthalmopathy. $\mathcal{f}$ Clin Endocrinol Metab 1988;67:565-70.

16 Boucher A, Bernard N, Zhang ZG, Rodien P, Salvi M, Wall JR. Nature of 64 $\mathrm{kDa}$ eye muscle and thyroid membrane proteins and their significance in thyroid-associated ophthalmopathy-an hypothesis. Autoimmunity 1994; 16:79-82.

17 Dong $Q$, Ludgate $M$, Vassart $G$. Cloning and sequencing of a novel $64-\mathrm{kDa}$ autoantigen recognized by patients with autoimmune thyroid disease. $f$ Clin Endocrinol Metab 1991;72:1375-81.

18 Kendler DL, Rootman J, Huber G, Davies T. A 64 kDa membrane antigen is a recurrent epitope for natural autoantibodies in patients with Graves' thyroid and ophthalmic diseases. Clin Endocrinol 1991;35:539-47.

19 Ross PB, Koenig RJ, Arscott P, Ludgate M. Tissue specificity and serologic reactivity of an autoantigen associated with autoimmune thyroid disease. $\mathcal{F}$ Clin Endocrinol Metab 1993;77:433-8.

20 Bernard NF, Nygen TN, Tyutyuikov A, Stolarski C, Scalise D, Genovese C et al. Antibodies against 1D, a recombinant $64-\mathrm{kDa}$ membrane protein, are associated with ophthalmology in patients with thyroid autoimmunity. Clin Immunol Immunopath 1994;70:225-33.

21 Schifferdecker E, Ketzler-Sasse U, Boehm BO, Ronsheimer HB, Scherbaum WA, Schoffling K. Re-evaluation of eye muscle autoantibody determination in Graves' ophthalmopathy: failure to detect a specific antigen by use of enzyme-linked immunosorbent assay, indirect immunofluorescence, and immunoblotting techniques. Acta Endocrinol 1989;121:643-50.

22 Ross PV, Koenig RJ, Arscott P, Ludgate M, Waier M, Nelson CC, et al. Tissue specificity and serologic reactivity of an autoantigen associated with sue specificity and serologic reactivity of an autoantigen associated

23 Elisei R, Weightman D, Kendall-Taylor P, Vassart G, Ludgate M. Muscle autoantigens in thyroid associated ophthalmopathy: the limits of molecular genetics. F Endocrinol Invest 1993;16:533-40.

24 Tandon N, Yan SL, Arnold K, Metcalfe RA, Weetman AP. Immunoglobulin class and subclass distribution of eye muscle and fibroblast antibodies in patients with thyroid-associated ophthalmopathy. Clin Endocrinol 1994;40: 629-39.

25 Wall JR, Triller H, Boucher A, Bernard NF, Salvi M, Ludgate M. Antibodies reactive with an intracellular epitope of a recombinant $64 \mathrm{kDa}$ thyroid and eye muscle protein in patients with thyroid autoimmunity and ophthalmopathy. $\Im$ Endocrinol Invest 1993;16:863-8.

26 Wall JR, Triller H, Chung F, Tsao M, Boucher A, Rodien P, et al. Cross-reactive antibodies in the serum of balb/c mice immunized with thyroid or eye muscle membranes. F Endocrinol Invest 1994;17:105-12.

27 Arnold K, Tandon N, McIntosh RS, Elisei R, Ludgate M, Weetman AP. T cell responses to orbital antigens in thyroid-associated ophthalmopathy. Clin Exp Immunol 1994;96:329-34.

28 Kiljanski JI, Nebes V, Wall JR. The ocular muscle cell is a target of the immune system in

29 Foss AJE, Fisher EW, McDonald N, Lawson J, Gregrson R, Fells P. The site of autoantigen and dysthyroid eye disease: the significant negative. Eye of autoantigen

30 Bahn RS, Heufelder AE. Pathogenesis of Graves' ophthalmopathy. N Engl $f$ Med 1993;329:1468-75.

31 Heufelder AE, Bahn RS. Detection and localization of cytokine immunoreactivity in retro-ocular connective tissue in Graves' ophthalmopathy. Eur f Clin Invest 1993;23:10-17.

32 Bahn RS. The fibroblast is the target cell in the connective tissue manifestations of Graves' disease. Int Arch Allergy Immunol 1995;106:213-8.

33 Heufelder AE, Bahn RS, Smith TJ. Regulation by glucocorticoids of interferon gammainduced HIA-DR antigen expression in cultured human orbital fibroblasts. Clin Endocrinol 1992;37:59-63.

34 Heufelder AE, Wenzel BE, Bahn RS. Glucocorticoids modulate the synthesis of expression of a $72-\mathrm{kDa}$ heat shock protein culture in Graves' retroocular fibroblasts. Acta Endocrinol 1993;128:41-50.

35 Ciocca DR, Oesterreich S, Chamness GC, McGuire WL, Fuqua SAW. Biological and clinical implication of heat shock protein 27000 (Hsp27): a review. $¥$ Natl Cancer Inst 1993;85:1558-70.

36 Heufelder AE, Bahn RS. Graves' immunoglobulins and cytokines stimulate the expression of intercellular adhesion molecule-1 (ICAM-1) in cultured Graves' orbital fibroblasts. Eur $\mathcal{F}$ Clin Invest 1992;22:529-37.

37 Heufelder AE, Wenzel BE, Gorman CA, Bahn RS. Detection, cellula localization, and modulation of heat shock proteins in cultured fibroblasts from patients with extrathyroidal manifestations of Graves' disease. $\mathcal{f}$ Clin Endocrin Soc 1991;73:739-45.

38 Heufelder AE, Bahn RS. Modulation of Graves' orbital fibroblast proliferation by cytokines and glucocorticoid receptor agonists. Invest Ophthalmol Vis Sci 1994;35:120-7.

39 Imai Y, Odajima R, Inoue Y, Sishiba Y. Effect of growth factors on hyaluronate and proteoglycan synthesis by retroocular tissue fibroblasts of Graves ophthalmopathy in culture. Acta Endocrinol 1992;126:541-52.

40 Bahn RS, Heufelder AE. Retroocular fibroblasts: important effector cells in Graves' ophthalmopathy. Thyroid 1992;2:89-94.

41 Metcalfe RA, Weetman AP. Stimulation of extraocular muscle fibroblasts by cytokines and hypoxia: possible role in thyroid-associated ophthalmopathy. Clin Endocrinol 1994;40:67-72.

42 Hudson HL, Levin L, Feldon SE. Graves' exophthalmos unrelated to extraocular muscle enlargement. Superior rectus muscle inflammation may induce venous obstruction. Ophthalmology 1991;98:1495-9.

43 Benning H, Lieb W, Kahaly G, Grehn F. Color Doppler ultrasound finding in patients with thyroid ophthalmopathology. Ophthalmology 1994;91:20-5.

44 Bahn RS, Dutton CM, Heufelder AE, Sarker G. A genomic point mutatio in the extracellular domain of thyrotropin receptor in patient with Graves' ophthalmopathy. $\mathcal{F}$ Clin Endocrin Metab 1994;78:256-60.
45 Bromberg N, Romaldini JH, Werner RS, Sgarbi JA, Werner MC. The evolution of Graves' ophthalmopathy during treatment with antithyroid drug alone and combined with triiodothyronine. $\mathcal{F}$ Endocrinol Invest 1992;15:191-5.

46 Karlsson FA, Kahlberg PA, Jansson R, Westermark K, Enoksson P. Importance of TSH receptor activation in the development of severe endocrine ophthalmopathy. Acta Endocrinol (Copenh) 1989;121 (suppl 2):132-41.

47 Sjoberg HE, Saaf M, Bostrom L, Lundell G, Tallstedt L. Observations on progress periods in Graves' ophthalmopathy. Acta Endocrinol (Copenh) 1989;121 (suppl 2):179-81.

48 Tallstedt L, Lundell G, Torring O, Wallin G, Ljunggren JG, Blomgren H, et al. Occurrence of ophthalmopathy after treatment for Graves' hyperthyroidism. $N$ Engl $\mathcal{Y}$ Med 1992;326:1733-8.

49 DeGroot LJ, Gorman CA, Pinchera A, Bartalena L, Marocci C, Wiersinga WM, et al. Therapeutic options: radiation and Graves' ophthalmopathy. $\mathcal{F}$ Clin Endocrinol Metab 1995;80:339-52.

50 Mendlovic DB, Saeed-Zafar M. Ophthalmology after treatment for Graves' hyperthyroidism. N Engl f Med 1992;327:1320-1.

51 DeGroot LJ, Mangklabruks A, McCormick M. Comparison of RA I-131 treatment protocols for Graves' disease. F Endocrinol Invest 1990;13:111-8.

52 Sridama V, DeGroot LJ. Treatment of Graves' disease and the course of ophthalmopathy. Am $\mathcal{F}$ Med 1989;87:70-3.

53 Prummel MF, Wiersinga WN. Medical management of Graves' ophthalmopathy. Thyroid 1995,5:231-4.

54 Barth A, Probst P, Burgi H. Identification of a subgroup of Graves' disease patients at higher risk for severe ophthalmopathy after radioiodine. $\mathcal{f}$ Endopatients at higher risk for sever
crinol Invest 1991;14:209-12.

55 Marcocci C, Bartalena F, Bogazzi G, Bruno-Bossio G, Pinchera A Relationship between Graves' ophthalmopathy and type of treatment of Graves' hyperthyroidism. Thyroid 1992;2:171-8.

56 Pequegnat EP, Mayberry WE, McConahey WN, Wyse EP. Large doses of radioiodine in Graves' disease: effect on ophthalmopathy and long-acting thyroid stimulator. Mayo Clin Proc 1967;42:802-11.

57 Bartalena L, Marcocci C, Bogazzi F, Panicucci M, Lepri A, Pinchera A. Use of corticosteroids to prevent progression of Graves' ophthalmopathy after radioiodine therapy for hyperthyroidism. N Engl ₹ Med 1989;321:1349-52.

58 Tallstedt L, Lundell G, Blomgren H, Bring J. Does early administration of thyroxine reduce the development of Graves' ophthalmopathy after radioiodine treatment. Eur $₹$ Endocrinol 1994;130:494-7.

59 Wartofsky L. Has the use of antithyroid drugs for Graves' disease become obsolete? Thyroid 1993;3:335-44.

60 Segers, O, Musch, W, Schoors, DF. Early complications of radioiodine treatment for hyperthyroidism. Acta Clin Belg 1993;48:253-8.

61 Karlsson F, Westermark, K, Dahlberg, PA, Jansson R, Enoksson P. Ophthalmopathy and thyroid stimulation. [Letter] Lancet 1989;2:691.

62 Walfish PG, Tseng $\mathrm{KH}$. Intrathyroidal activated (Ia+) T-lymphocyte CD+ subsets and B cells in Graves' hyperthyroidism respond rapidly to propylthiouracil therapy: demonstration using fine needle aspirates and two-colour laser flow cytometry. Autoimmunity 1992;13:35-41.

63 McIver B, Rae P, Beckett G, Wilkinson E, Gold A, Toft A. Lack of effect of thyroxine in patients with Graves' hyperthyroidism who are treated with an antithyroid drug. $N$ Engl f Med 1996;334:220-4.

64 Wiersinga WM, Smit T, van der Gaag Mourits M, Koornneef L. Clinica presentation of Graves' ophthalmopathy. Ophthalmic Res 1989;21:73-82.

65 Bartels EX, Irie M. Thyroid function in patients with progressive exophthalmos: study of 117 cases requiring orbital decompression. In: PittRivers R, ed. Advances in thyroid reasearch. Transactions of the Fourth International Goiter Conference. London: Pergamon Press, 1961:163-70.

66 Ivy HK. Medical approach to ophthalmopathy of Graves' disease. Mayo Clin Proc 1972;47:980-5.

67 Young LA. Dysthyroid ophthalmopathy in children. 7 Pediatr Ophthalmol Strabismus 1982;16:105-7.

68 Metz HS, Woolf PD, Patton ML. Endocrine ophthalmopathy in adolescence. F Pediatr Ophthalmol Strabismus 1982;19:58-60.

69 Bartley GB. Epidemiologic characteristics and clinical course of ophthalmopathy associated with autoimmune thyroid disease in Olmstead County, Minnesota. Trans Am Ophthal Soc 1994;92:477-588.

70 Perros P, Crombie Al, Matthews JNS, Kendall-Taylor P. Age and gender influence the severity of thyroid-associated ophthalmopathy: a study of 101 patients attending a combined thyroid-eye clinic. Clin Endocrinol 1993;38:367-72.

71 Tellez M, Cooper J, Edmonds C. Graves' ophthalmopathy in relation to cigarette smoking and ethnic origin. Clin Endocrinol 1992;36:291-4.

$72 \mathrm{Hagg} \mathrm{E}$, Asplund $\mathrm{K}$. Is endocrine ophthalmopathy related to smoking? $B M \mathcal{F}$ 1987;295:634-5

73 Balzas C, Stenszky V, Farid NR. Association between Graves' ophthalmopathy and smoking. Lancet 1990;336:74

74 Bartalena L, Martino E, Marcocci C, Bogazzi F, Panicucci M, Velluzzi F, $e$ al. More on smoking habits and Graves' ophthalmopathy. 7 Endocrinol Invest 1989;12:733-7.

75 Shine B, Fells P, Edwards OM, Weetman, AP. Association between Graves' ophthalmopathy and smoking. Lancet 1990;335:1261-3.

76 Nunnery WR, Martin RT, Heinz GW, Gavin TJ. The association of cigarette smoking with clinical subtypes of ophthalmic Graves' disease. Ophthal Plast Reconstr Surg 1993:9:77-82.

77 Winsa B, Mandahl A, Karlsson FA. Graves' disease, endocrine ophthalmopathy and smoking. Acta Endocrinol 1993;128:156-60.

78 Char DH. The ophthalmopathy of Graves' disease. Med Clin NA 1991;75:97-119.

79 Prummel MF, Mourits MP, Berghout A, Krenning EP, van der Gaag R, Kornneef $\mathrm{L}$, et al. Prednisone and cyclosporine in the treatment of severe Graves' ophthalmopathy. N Engl f Med 1989;321:1353-9.

80 Kahaly G, Schrezenmeir J, Kruse U, Schweikert B, Meuer S, Muller W, et al Cyclosporin and prednisone in treatment of Graves' ophthalmopathy: a controlled, randomized, prospective study. Eur $f$ Clin Invest 1986;16:415-22.

81 Bartalena L, Marcocci C, Chiovato L Lepri A Andreani D, Cavallacci G, al. Orbital cobalt irradiation combined with systemic corticosteroids for Graves' ophthalmopathy: comparison with systemic corticosteriods alone. Graves' ophthalmopathy: comparison with

82 Peterson IA, Kriss JP, McDougall IR, Donaldson SS. Prognostic factors in the radiotherapy of Graves' ophthalmopathy. Int $\mathcal{F}$ Radiat Oncol Biol Phys 1990;19:259-64.

83 Fries PD, Fohrman DS, Char DH. Phorbol ester induced orbital myositis. Arch Ophthalmol 1987;105:1273-6.

84 Hiromatsu Y, Kojima K, Ishisaka N, Tamaka K, Sato M, Nonaka K, et al. The role of magnetic resonance imaging in thyroid-associated 
Ophathalmopachy: its predictive value for therespeutic outcome in immunosuppressive therepy. Thyroid 1992;2:299-305.

85 Just M, Kahnly G, Higar HP, Roder HP, Kutener J, Beger J, at al Gruves' Ophthalmopatihy. role of MR imaging in radietion therepy. Radiolosy 1991; 175:187-90.

86 Hosten VN, Schomer W, Lietz A, Wenred KW. Der Kranltheitsverdafibei dex

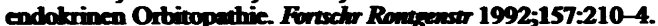

87 Ohniehi T, Noguchi S, Muralomi N, Tiür J, Harmo M, Kmamoto H, et al.

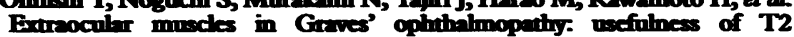

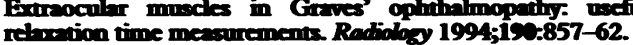

88 Demer J, Kerman BM. Comparison of standandived echography with magnetic resonance imaging to measure erraccular muscle sime. Am $\mathrm{J}$ Opinatinal 1994;118-351-61.

89 Wulc AE, Popp JC, Bartiet SP. I nteral woll advancement in orbinal decompression. Opitulabalesy 1990;97:1358-69.
90 Garrity JA, Fatourechi V, Bergstralh EJ, Bartley GB, Beatty CW, DeSanto LW, a al. Results of transantral orbital decompression in 428 patients with severe Greves' ophthalmopathy. Am f Ophathabnol 1993;116:533-47.

91 Trobel S, Krrim M, Moore S. Orbital fat removal. Decompression from Graves' Ophthalmoperthy. Ophuthabmalosy 1993;100:674-82.

92 Kennedy DW, Goodstein MI, Mitler NR, Zinreich SJ. Endoscopic transngsel atbitl decompression. Anch Orolenymod Head Neck Surg 1990;116:275-82.

93 Kwehner BJ. Torsional diplopia affer transantral orbital decompression and erirecular muscle surgery associated with Graves' orbitopathy. Am f Ophextraccular muscle surgery as

$94 \mathrm{Kraus}$ DJ, Bullock D. Treatment of thyroid ocular myopathy with Kraus DJ, Bullock J. Treatment of thyroid ocular myopathy with adjustable and nonadjust

95 For DA Biological therapies: a novel approach to the treatment of autoimmune disease. Am J Med 1995;99:82-8. 